УДК 621.6

\title{
ИСПОЛЬЗОВАНИЕ ГИБКИХ БЕТОННЫХ МАТОВ ДЛЯ ЗАЩИТЫ ПОДВОДНЫХ ТРУБОПРОВОДОВ
}

\author{
Завалина Елена Александровна \\ ст. преподаватель \\ ФГБОУ ВО «ВГТУ»
}

\begin{abstract}
Аннотация: В работе проведены расчётно-теоретические сравнительные исследования гибких бетонных матов с усиленной шероховатостью и с «донной присоской». Результаты исследования показали, что устойчивость гибких бетонных матов с «донной присоской» существенно повышается с увеличением глубины водотока, поэтому такие покрытия целесообразно применять при достаточно большой глубине водотока. (H >1 м), а повышение устойчивости сдвигу гибких бетонных матов с усиленной шероховатостью при воздействии на них потока воды, определяется высотой выступов шероховатости и глубиной погружения их в грунт и существенно зависит от свойств защищаемого грунта.

Ключевые слова: Гибкие бетонные маты, устойчивость бетонного блока, подстилающий грунт, усиленная шероховатость, донная присоска.
\end{abstract}

\section{USING FLEXIBLE CONCRETE MATS TO PROTECT UNDERWATER PIPELINES}

\section{Zavalina Elena Aleksandrovna senior Lecturer} Voronezh State Technical University

\begin{abstract}
In this paper a computational and theoretical comparative study of flexible concrete mats with reinforced roughness and with "bottom sucker" has been carried out. The research results have shown that the stability of flexible concrete mats with "bottom sucker" significantly increases with increasing watercourse depth, so it is appropriate to apply such covers at a sufficiently high watercourse depth. (H > $1 \mathrm{~m}$ ), and the increase in shear stability of flexible concrete mats with reinforced roughness when exposed to water flow, is determined by the height of roughness
\end{abstract}


projections and the depth of their immersion into the ground and depends significantly on the properties of the protected soil.

Key words: Flexible concrete mats, concrete block stability, subgrade, reinforced roughness, bottom sucker.

\section{Введение.}

Гибкие бетонные маты, состоящие из бетонных блоков, связанных между собой соединительным канатом, находят все большее применение для защиты подводных переходов трубопроводов, крепления откосов различных гидросооружений, укрепления берегов водоемов и водотоков, при строительстве дорог и других отраслях хозяйства страны. Однако, крепления, выполненные из гибких бетонных матов, работают в сложных условиях, характеризуемых воздействиями на них различных гидродинамических процессов, что может привести к нарушению устойчивости и прочности защитного покрытия.

С целью повышения устойчивости положения защитных матов на грунте в условиях водных потоков ООО «Спецпром 1» разработало новые конструкции гибких бетонных матов с усиленной шероховатостью нижней поверхности бетонного блока, примыкающей к защищаемому грунту (рис.1a), и с «донной присоской» (рис.1б).

a)

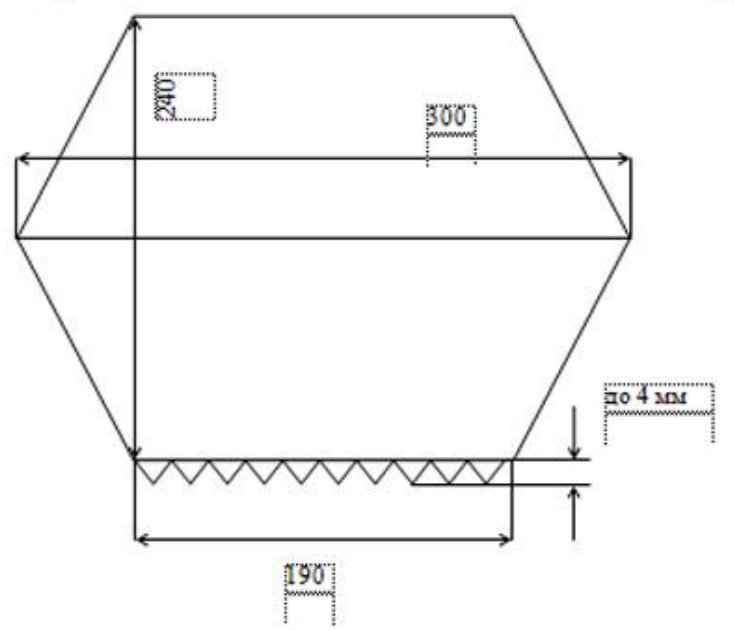

๑)

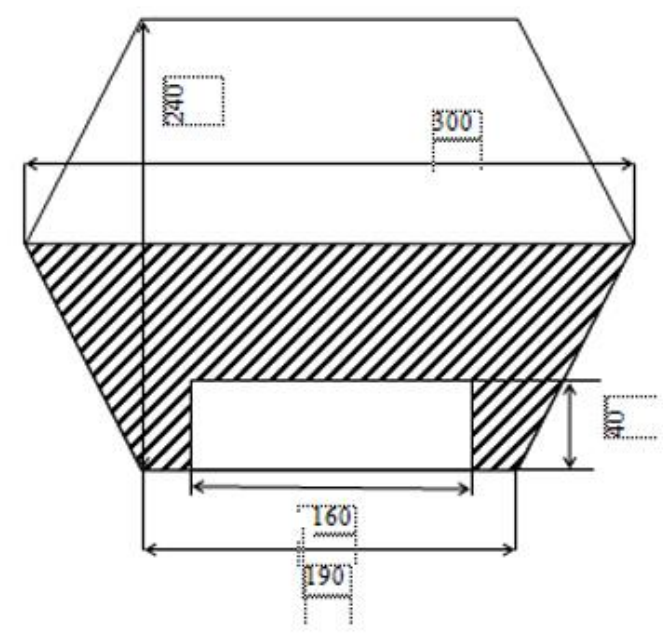

Рис. 1. Новые конструкции гибких бетонных матов а) с усиленной шероховатостью; б) с «донной присоской» 


\section{ИННОВАЦИОННОЕ РАЗВИТИЕ НАУКИ: ФУНДАМЕНТАЛЬНЫЕ И ПРИКЛАДНЫЕ ПРОБЛЕМЫ}

Повышение устойчивости бетонного блока с усиленной шероховатостью достигается за счёт увеличения горизонтальной силы, противодействующей силе гидродинамического давления воды на переднюю торцевую поверхность блока, обращённую навстречу скорости движения воды. При этом, эту противодействующую силу можно представить как сумму силы трения бетонного блока о подстилающий грунт и силу пассивного отпора грунта, возникающую при погружении выступов шероховатости в подстилающий грунт. Чем на большую глубину погружены выступы шероховатости в глубину тем больше сила пассивного отпора грунта. Следовательно, устойчивость гибких бетонных матов с усиленной шероховатостью будет определяться высотой выступов шероховатости и глубиной погружения их в грунт, т.е. свойствами защищаемого грунта.

Повышение устойчивости бетонного блока $\mathrm{c}$ «данной присоской» достигается за счёт увеличения силы трения его о подстилающий грунт при действии, в этом случае, дополнительной силы гидростатического давления воды на бетонный блок. Возникновение этой силы возможно только при плотном прилегании бетонного блока к водонепроницаемой или малопроницаемой грунтовой поверхности (например, глинистый грунт). Если грунтовая поверхность водопроницаема (например, галечный или песчаный грунт), то эта сила отсутствует и не наблюдается эффекта «присасывания» бетонного блока к защищаемой поверхности.

В связи с большой площадью соприкосновения бетонного блока с грунтом и неровностью защищаемой поверхности, а также различной высотой выступов шероховатости, этот эффект «присасывания» не будет проявляться для бетонных блоков обычной конструкции и бетонных блоков с усиленной шероховатостью (рис.1а), так, как при этом не возникает плотное прилегание бетонного блока к защищаемой поверхности.

Гибкие бетонные маты с «донной присоской» состоят из бетонных блоков, имеющих на нижней поверхности, примыкающей к защищаемому грунту, выемку определённой глубины (рис.1б.). Наличие этой выемки позволяет значительно уменьшить площадь соприкосновения бетонного блока с защищаемым грунтом, которая в этом случае будет определяться только толщиной кромки между выемкой и боковыми гранями бетонного блока.

В связи с небольшой площадью соприкосновения бетонного блока с защищаемой поверхностью кромка бетонного блока под действием силы 
тяжести будет погружаться в грунт, уплотнять его и, при наличии водонепроницаемого грунта, изолировать нижнюю поверхность бетонного блока от воздействия гидростатического давления воды. В этом случае гидростатическое давление будет действовать только на верхнюю поверхность бетонного блока, создавая вертикальную силу, направленную вниз и прижимающую бетонный блок к защищаемой поверхности грунта. При этом осуществляется как бы эффект «присасывания» бетонного блока к защищаемой поверхности грунта. Так как сила трения прямо пропорциональна силе нормального давления, то наличие дополнительной силы, прижимающей бетонный блок к поверхности грунта, повышает устойчивость бетонного мата от воздействия потока воды.

При этом, при погружении кромки бетонного блока в грунт, также будет действовать сила пассивного отпора грунта, повышающая устойчивость бетонного блока.

Учитывая, что сила гидростатического давления воды пропорциональна глубине водотока, очевидно, что устойчивость бетонного мата с «донной присоской» будет увеличиваться с увеличением глубины водотока.

Таким образом, использование гибких бетонных матов с «донной присоской» может быть эффективно только при защите водонепроницаемого или малопроницаемого грунта с проявлением эффекта «присасывания» бетонного блока к защищаемой поверхности, что достигается соответствующим выбором толщины кромки между выемкой и боковыми гранями бетонного блока. Очевидно, толщина этой кромки должна выбираться из конструктивных соображений, учитывающих различные факторы.

В настоящей работе, в качестве примера, приводятся результаты сравнительного расчетно-теоретического исследования эффективности применения для защиты русла водотока модели УГЗБМ-105, выполненной по ТУ [1], и разработанных на её основе моделей с усиленной шероховатостью и «донной присоской» (в дальнейшем эти модели будут обозначаться УГЗБМ105ш и УГЗБМ-105п). Основные геометрические размеры этих моделей показаны на рис.1.

\section{1.Постановка задачи.}

Для определения сравнительной устойчивости указанных моделей УГЗБМ к воздействию потока воды были выбраны следующие условия расположения их на защищаемой поверхности русла водотока. 
Расчет №1. Защищаемая поверхность - гравийно-галечный и крупнопесчаный неразрываемый грунт. Очевидно, в этом случае полотна УГЗБМ-105 будут уложены без погружения бетонных блоков в грунт и сцепления их с частицами грунта, а полотна УГЗБМ-105ш и полотна УГЗБМ105п - с погружением бетонных блоков на величину выступов шероховатости или величину выемки «донной присоски» (рис.2). При этом во всех случаях не возникает эффект «присасывания» бетонных блоков к грунту.

a)

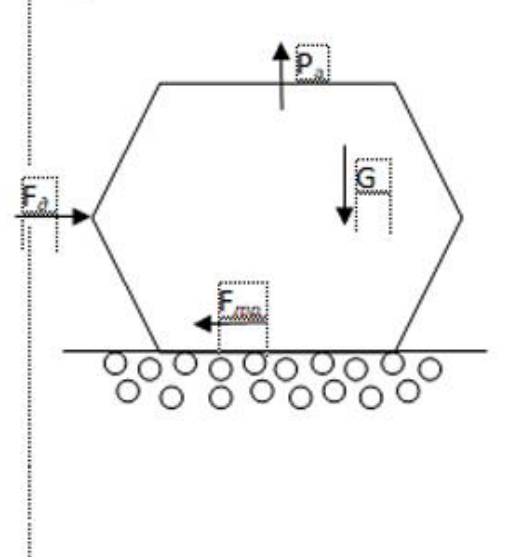

6)

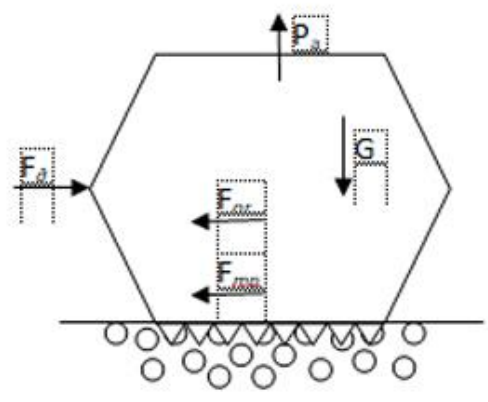

в)

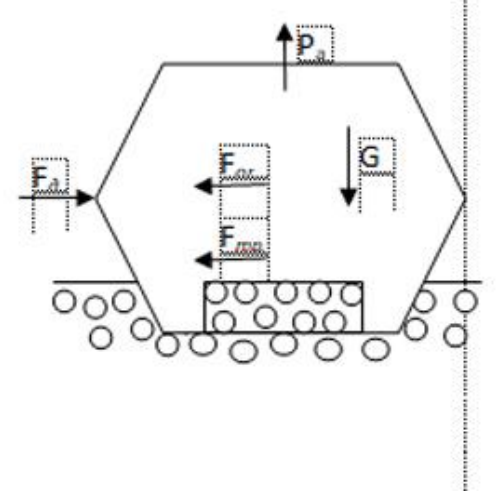

Рис. 2. Схема сил, действующих на УГЗБМ на гравийно-галечном грунте а) УГЗБМ-105; б) УГЗБМ-105ш; в) УГЗБМ-105п

Расчет №2. Защищаемая поверхность представляет собой песок средней крупности. Учитывая острые вершины выступов шероховатости и малую толщину кромки выемки «донной присоски» (15мм) есть все основания полагать, что под действием силы тяжести бетонные блоки будут погружаться в песчаный грунт на величину выступов шероховатости или величину выемки «донной присоски», то есть положение УГЗБМ на грунте будет соответствовать рис.3. При этом также будет отсутствовать эффект «присасывания» бетонных блоков к грунту. 


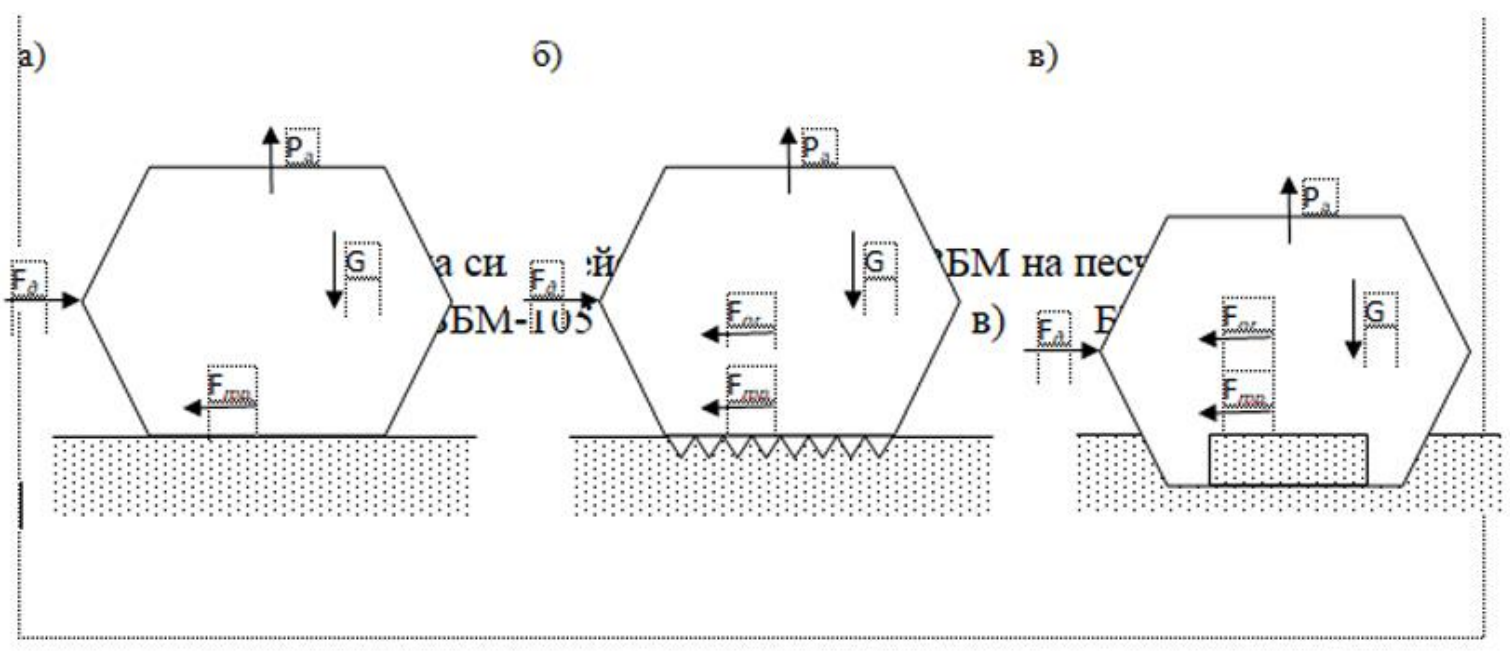

Рис. 3. Схема сил, действующих на УГЗБМ на песчаном грунте а) УГЗБМ-105; б) УГЗБМ-105ш; в) УГЗБМ-105п

Расчет №3. Защищаемая поверхность - глинистый трудно размываемый грунт. В этом случае полотна УГЗБМ-105 будут уложены без погружения бетонных блоков в грунт, а в связи с большой площадью соприкосновения бетонного блока с грунтом и неровностью защищаемой поверхности будет отсутствовать эффект «присасывания».

Полотна УГЗБМ-105ш будут уложены с погружением вершин выступов шероховатости в грунт. Но так как высота выступов разная, изменяющаяся от 0 до 4 мм, то при этом не происходит плотного прилегания бетонного блока к защищаемой поверхности и эффект «присасывания» при этом также будет отсутствовать.

В связи с малой толщиной кромки выемки «донной присоски» УГЗБМ105п под действием силы тяжести и гидростатического давления воды будет плотно прилегать к защищаемой поверхности по всей кольцевой площади нижней поверхности бетонного блока без погружения бетонного блока в плотный глинистый грунт (рис.4). При этом будет наблюдаться эффект «присасывания» бетонного блока к защищаемому грунту. 


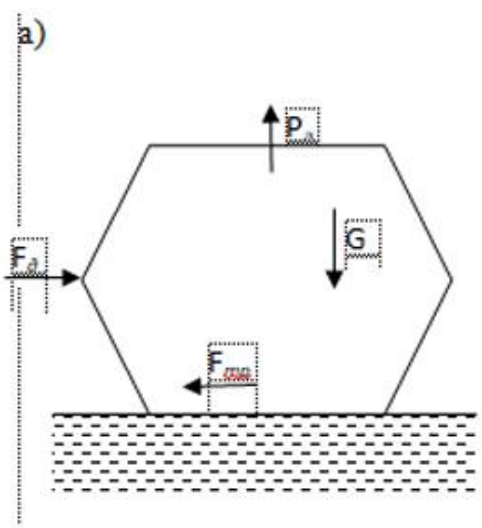

๑)

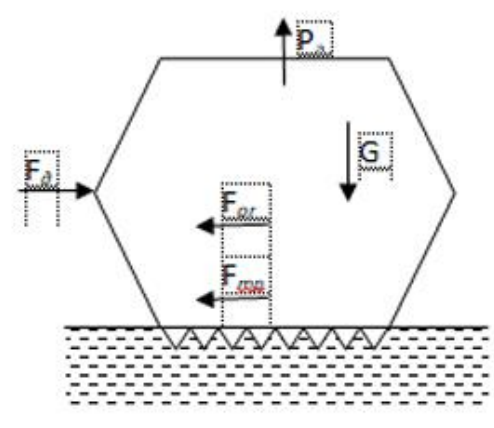

в)

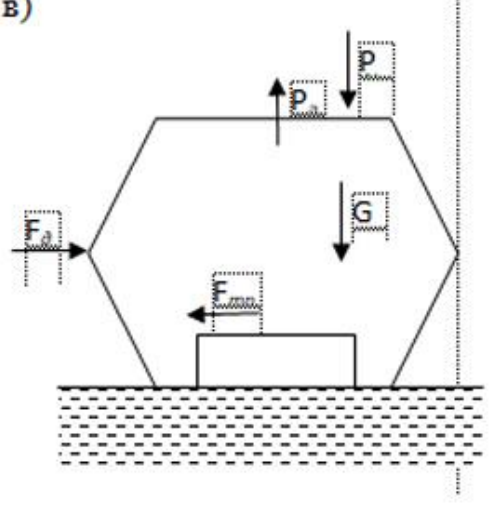

Рис. 4. Схема сил, действующих на УГЗБМ на глинистом грунте а) УГЗБМ-105; б) УГЗБМ-105ш; в) УГЗБМ-105п

Расчет №4. Защищаемая поверхность - песчано-иловый грунт. В этом случае, в связи с большой пористостью грунта и малым значением модуля сжимаемости, под действием силы тяжести и гидростатического давления будет происходить самопогружение бетонных блоков УГЗБМ в грунт, с плотным прилеганием нижней поверхности блока к поверхности грунта и возникновением эффекта «присасывания». Учитывая, что устойчивость УГЗБМ на защищаемом грунте увеличивается с увеличением глубины погружения бетонных блоков в грунт, расчетный анализ был проведен для наиболее неблагоприятного случая, когда песчано-иловый грунт достаточно плотный и УГЗБМ-105 уложены без погружения бетонных блоков, а УГЗБМ-105ш и УГЗБМ-105п с погружением их на величину выступов шероховатости или на величину выемки «донной присоски» соответственно, (рис.5). При этом, во всех случаях учитывалась сила гидростатического давления воды, прижимающая УГЗБМ к поверхности защищаемого грунта и обуславливающая эффект «присасывания». 

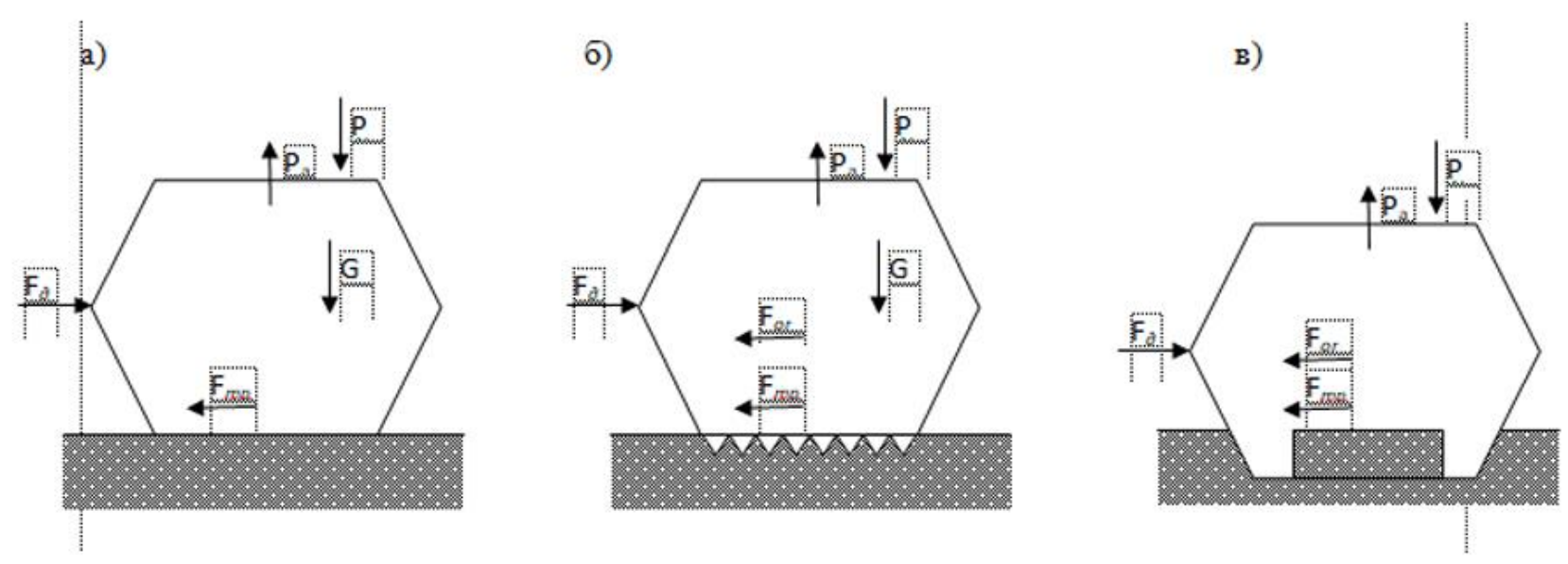

Рис. 5. Схема сил, действующих на УГЗБМ на песчано-иловом грунте а) УГЗБМ-105; б) УГЗБМ-105ш; в) УГЗБМ-105п

При расчетах для каждых УГЗБМ на защищаемой поверхности была определена минимальная скорость потока воды, способная сместить (приподнять или сдвинуть) крайний ряд бетонных блоков УГЗБМ, рассматриваемых моделей.

\section{2.Физико-математическое обеспечение задачи.}

Для сравнительной оценки устойчивости УГЗБМ к воздействию потока воды необходимо определить все силы, которые действуют на отдельный бетонный блок, находящийся в потоке на защищаемой поверхности в разных положениях.

На бетонные блоки крайнего ряда УГЗБМ будут действовать следующие силы:

1. Сила тяжести блока $\mathrm{G}$, приложенная в его центре тяжести и направленная вертикально вниз. Эта сила равна весу бетонного блока.

2. Архимедова подъемна сила $\mathrm{P}_{\mathrm{a}}$, направленная вертикально вверх и приложенная в центре тяжести блока:

$$
P_{a}=\gamma_{\mathrm{B}} v_{6}
$$

где $\gamma_{\mathrm{B}}$ - объемный вес воды $\left(\gamma_{\mathrm{B}}=1000\right.$ кг $\left./ \mathrm{m}^{3}\right) ; v_{б}$ - объем одного блока УГЗБМ.

3. Горизонтальная сила лобового давления $\mathrm{F}_{\partial}$, обусловленная гидродинамическим давлением потока воды на бетонный блок: 


$$
F_{\text {д }}=\rho C_{\text {д }} S \frac{U^{2}}{2},
$$

где $\rho$ - плотность воды; $C_{\text {д }}$ - коэффициент лобового сопротивления, зависящий от скорости потока, формы обтекаемого тела и состояния его поверхности; $S$ - площадь миделевого сечения, то есть площадь сечения тела плоскостью, перпендикулярной направлению потока; $U$ - скорость, с которой жидкость воздействует на погруженное в нее тело.

4. Сила гидростатического давления воды на бетонный блок $\mathrm{P}$, направленная вертикально вниз:

$$
\mathrm{P}=\gamma_{\mathrm{B}} H \mathrm{~S}_{\mathrm{p}},
$$

где $H$ - глубина воды в потоке; $\mathrm{S}_{\mathrm{p}}$ - площадь действия силы давления.

5. Сила трения бетонного блока о подстилающий грунт $\mathrm{F}_{\text {тр }}$, равная произведению коэффициента трения на силу нормального давления и направленная горизонтально навстречу скорости движения воды. Для рассматриваемого случая:

$$
F_{\text {тр }}=f\left(G+P-P_{a}\right),
$$

где $f$ - коэффициент трения бетонного блока о подстилающий грунт.

6. Сила пассивного отпора грунта $\mathrm{F}_{\text {or }}$, действующая в случае погружения УГЗБМ в грунт, определяемая по формуле:

$$
\mathrm{F}_{\mathrm{or}}=\frac{1}{2} \gamma L t^{2} \cdot \operatorname{tg}^{2}\left(45+\frac{\varphi}{2}\right)+2 C L t \cdot \operatorname{tg}\left(45+\frac{\varphi}{2}\right),
$$

где $\gamma$ - объемный вес грунта; $L$ - средняя длина погружения в грунт части бетонного блока; $t$ - глубина погружения в грунт бетонного блока; $\varphi$ угол внутреннего трения грунта; $C$ - коэффициент сцепления грунта.

Очевидно, что отрыв бетонного блока от дна водотока, скручивание и дрейф полотна УГЗБМ в потоке воды может произойти, если горизонтальная сила лобового давления $\mathrm{F}_{\text {д }}$ будет превосходить суммарную силу трения $\mathrm{F}_{\text {тр }}$ и силу пассивного отпора грунта $\mathrm{F}_{\text {or }}$.

$$
F_{\text {д }} \geq F_{\text {тр }}+F_{o r} .
$$


Подставляя найденные значения сил из этого соотношения можно найти предельную скорость потока, способную оторвать от дна бетонные блока УГЗБМ:

$$
U \geq \sqrt{\frac{2}{\rho C_{\text {B }}}\left[f\left(G+P+P_{a}\right)+F_{o r}\right]} .
$$

Найденная скорость является придонной скоростью, то есть скоростью у дна реки. В соответствии с рекомендациями [2] скорость у дна реки составляет порядка $70 \%$ средней скорости течения $\mathrm{U}_{\mathrm{cp}}$, представляющей собой частное от деления общего расхода воды на площадь живого сечения реки. Тогда очевидно, что предельная скорость течения, при которой возможен отрыв УГЗБМ от дна, составляет:

$$
U_{\text {cp }}=\frac{U}{0,7}=1,43 U
$$

Согласно рекомендациям [2,3] при расчетах приняты следующие значения коэффициента трения бетонного блока о подстилающий грунт : $\mathrm{f}=0,2$ - мокрые глины; f=0,3 - песчано-иловый грунт; f=0,35 - мокрый песок средней крупности; f=0,5 - мокрый гравий и галька.

Таблица 1

\begin{tabular}{|c|c|c|c|c|}
\hline \multirow{2}{*}{ Параметр } & \multicolumn{4}{|c|}{ Грунты } \\
\hline & Глина & Ил & Песок & Галька \\
\hline Объемный вес грунта $\gamma$, кг/м³ & 2600 & 2200 & 2500 & 2800 \\
\hline Угол внутреннего трения $\varphi$, град & 20 & 15 & 36 & 43 \\
\hline $\begin{array}{l}\text { Коэффициент сцепления грунта } \\
\text { С, кг/см² }\end{array}$ & 0,04 & 0,03 & 0,02 & 0,01 \\
\hline
\end{tabular}

Численные значения параметров грунтов, используемых в расчетах

В табл.1приведены средние значения параметров грунтов, используемых в расчетах согласно рекомендациям [4,5].

Коэффициент лобового сопротивления, согласно рекомендациям [6], во всех случаях принят одинаковым $\mathrm{C}_{д}=2$. 


\section{3.Результаты вычислений и их анализ.}

Результаты проведенных вычислений основных параметров, с использованием указанных выше формул физико-математического обеспечения задачи, приведены в табл.2,3,4,5,6 и 7.

В табл.2 расчетные параметры соответствуют моделям УГЗБМ, уложенным на гравийно-галечный неразмываемый грунт согласно схеме рис.2. При расчете предельной скорости потока в этом случае сила гидростатического давления воды Р согласно формуле(3) не учитывалась.

Как видно из этой таблицы УГЗБМ модели 105 и 105ш обладают в этом случае практически одинаковой устойчивостью при воздействии на них потока воды. Это обусловлено тем, что модель УГЗБМ-105ш с усиленной шероховатостью имеет малую величину погружения в грунт бетонного блока, $\mathrm{t}=4 \mathrm{Mм}$, поэтому сила пассивного отпора грунта незначительна и составляет всего $\mathrm{F}_{\mathrm{or}}=0,37$ кг. Устойчивость УГЗБМ-105п в этом случае может быть повышена примерно на $30 \%$ за счет зацепления кольцевой выемки бетонного блока за частицы гравийно-галечного грунта. Это зацепление возможно, так как глубина выемки $\mathrm{t}=4 \mathrm{~cm}$, соответствует среднему размеру частиц этого грунта.

Таблица 2

\section{Результаты расчета устойчивости УГЗБМ, уложенных на гравийно-} галечный грунт

\begin{tabular}{|c|c|c|c|}
\hline \multirow[b]{2}{*}{ Расчетный параметр } & \multicolumn{3}{|c|}{ Модель УГЗБМ } \\
\hline & УГЗБМ-105 & $\begin{array}{c}\text { УГЗБМ- } \\
105 ш\end{array}$ & $\begin{array}{c}\text { УГЗБМ- } \\
105 \Pi\end{array}$ \\
\hline Площадь миделевого сечения, S, м² & 0,0588 & 0,0588 & 0,0506 \\
\hline Коэффициент лобового сопротивления, $\mathrm{C}_{\text {д }}$ & 2 & 2 & 2 \\
\hline $\begin{array}{l}\text { Средняя длина погруженной в грунт части } \\
\text { бетонного блока, L, м }\end{array}$ & 0 & 0,19 & 0,19 \\
\hline Глубина погружения в грунт бетонного блока, t, м & 0 & 0,004 & 0,04 \\
\hline Сила тяжести бетонного блока, G, кг & 33,9 & 33,9 & 31,3 \\
\hline Архимедова сила, $\mathrm{P}_{\mathrm{a}}$, кг & 14,5 & 14,5 & 13,4 \\
\hline Сила пассивного отпора грунта, $\mathrm{F}_{\mathrm{or}}$, кг & 0 & 0,37 & 5,75 \\
\hline $\begin{array}{l}\text { Предельная скорость потока, способная сместить } \\
\text { УГЗБМ, U, м/с }\end{array}$ & 1,82 & 1,86 & 2,41 \\
\hline
\end{tabular}


В табл.3 представлены расчетные параметры, соответствующие различным моделям УГЗБМ, уложенным на песчаный грунт согласно схеме рис.3.

Таблица 3

Результаты расчета устойчивости УГЗБМ, уложенных на песчаный грунт

\begin{tabular}{|l|c|c|c|}
\hline \multirow{2}{*}{ Расчетный параметр } & \multicolumn{3}{|c|}{ Модель УГЗБМ } \\
\cline { 2 - 4 } & УГЗБМ-105 & $\begin{array}{c}\text { УГЗБМ- } \\
105 ш\end{array}$ & $\begin{array}{c}\text { УГЗБМ- } \\
105 п\end{array}$ \\
\hline Площадь миделевого сечения, S, м & 0,0588 & 0,0588 & 0,0506 \\
\hline Коэффициент лобового сопротивления, $\mathrm{C}_{\text {д }}$ & 2 & 2 & 2 \\
\hline $\begin{array}{l}\text { Средняя длина погруженной в грунт части } \\
\text { бетонного блока, L, м }\end{array}$ & 0 & 0,19 & 0,19 \\
\hline $\begin{array}{l}\text { Глубина погружения в грунт бетонного блока, } \\
\text { t, м }\end{array}$ & 0 & 0,004 & 0,04 \\
\hline Сила тяжести бетонного блока, G, кг & 33,9 & 33,9 & 31,3 \\
\hline Архимедова сила, Ра, кг & 14,5 & 14,5 & 13,4 \\
\hline Сила пассивного отпора грунта, Fог, кг & 0 & 0,61 & 7,43 \\
\hline $\begin{array}{l}\text { Предельная скорость потока, способная } \\
\text { сместить УГЗБМ, U, м/с }\end{array}$ & 1,52 & 1,59 & 2,33 \\
\hline
\end{tabular}

Из сравнения табл.2 и 3 видно, что несмотря на то, что сила пассивного отпора песчаного грунта несколько увеличивается по сравнению с галечным за счет увеличения коэффициента сцепления, однако предельная скорость потока, способная сместить УГЗБМ, несколько снижается за счет уменьшения коэффициента трения с $\mathrm{f}=0,5$ до $\mathrm{f}=0,35$. Учитывая, что это снижение незначительно можно считать, что соответствующие модели УГЗБМ обладают практически одинаковой устойчивостью при расположении на песчаном и галечном грунте.

В табл.4 приведены расчетные параметры, соответствующие различным моделям УГЗБМ, уложенным на глинистый грунт согласно схеме рис.4. 
Таблица 4

Результаты расчета устойчивости УГЗБМ, уложенных на глинистый грунт

\begin{tabular}{|c|c|c|c|}
\hline \multirow{2}{*}{ Расчетный параметр } & \multicolumn{3}{|c|}{ Модель УГЗБМ } \\
\hline & УГЗБМ-105 & УГЗБМ-105ш & УГЗБМ-105п \\
\hline Площадь миделевого сечения, S, м² & 0,0588 & 0,0588 & 0,0588 \\
\hline Коэффициент лобового сопротивления, $\mathrm{C}_{\text {д }}$ & 2 & 2 & 2 \\
\hline $\begin{array}{l}\text { Средняя длина погруженной в грунт части } \\
\text { бетонного блока, L, м }\end{array}$ & 0 & 0,19 & 0 \\
\hline $\begin{array}{l}\text { Глубина погружения в грунт бетонного блока, } \\
\text { t, м }\end{array}$ & 0 & 0,004 & 0 \\
\hline Сила тяжести бетонного блока, G, кг & 33,9 & 33,9 & 31,3 \\
\hline Архимедова сила, $\mathrm{P}_{\mathrm{a}}$, кг & 14,5 & 14,5 & 13,4 \\
\hline $\begin{array}{l}\text { Сила пассивного отпора грунта } \\
\mathrm{F}_{\text {or, }} \text { кг }\end{array}$ & 0 & 0,716 & 0 \\
\hline $\begin{array}{l}\text { Площадь действия силы гидростатического } \\
\text { давления, } \\
\mathrm{SP}_{\mathrm{P}} \mathrm{m}^{2}\end{array}$ & 0 & 0 & 0,0361 \\
\hline $\begin{array}{l}\text { Сила гидростатического давления при глубине } \\
\text { Н=1м } \\
\text { P, кг }\end{array}$ & 0 & 0 & 36,1 \\
\hline $\begin{array}{l}\text { Предельная скорость потока, способная } \\
\text { сместить УГЗБМ, U, м/с }\end{array}$ & 1,15 & 1,25 & 1,92 \\
\hline
\end{tabular}

Как видно из таблицы УГЗБМ обладают наименьшей устойчивостью при расположении их на глинистом грунте. Однако за счет эффекта «присасывания» устойчивость УГЗБМ-105п при глубине воды Н=1м в 1,7 раза выше, чем УГЗБМ-105. Как видно из табл.5 устойчивость УГЗБМ-105п еще более повышается при увеличении глубины водотока.

Таблица 5

Результаты расчета устойчивости УГЗБМ-105п, уложенных на глинистый грунт при различной глубине водотока

\begin{tabular}{|l|c|c|c|c|c|}
\hline Глубина воды, Н, м & 1 & 2 & 3 & 4 & 5 \\
\hline Сила гидростатического давления, Р, кг & 36,1 & 72,2 & 108,3 & 144 & 180 \\
\hline Предельная скорость потока, U, м/с & 1,92 & 2,48 & 2,93 & 3,32 & 3,67 \\
\hline
\end{tabular}


В табл.6 представлены расчетные параметры, соответствующие различным моделям УГЗБМ, уложенным на песчано-иловый грунт согласно схеме рис.5.

Таблица 6

Результаты расчета устойчивости УГЗБМ, уложенных на песчано-иловый грунт

\begin{tabular}{|c|c|c|c|}
\hline \multirow[b]{2}{*}{ Расчетный параметр } & \multicolumn{3}{|c|}{ Модель УГЗБМ } \\
\hline & УГЗБМ-105 & $\begin{array}{c}\text { УГЗБМ- } \\
105 ш \\
\end{array}$ & $\begin{array}{c}\text { УГЗБМ- } \\
105 \Pi \\
\end{array}$ \\
\hline Площадь миделевого сечения, S, м² & 0,0588 & 0,0588 & 0,0506 \\
\hline Коэффициент лобового сопротивления, $\mathrm{C}_{д}$ & 2 & 2 & 2 \\
\hline $\begin{array}{l}\text { Средняя длина погруженной в грунт части } \\
\text { бетонного блока, L, м }\end{array}$ & 0 & 0,19 & 0,19 \\
\hline $\begin{array}{l}\text { Глубина погружения в грунт бетонного блока, } \\
\text { t, м }\end{array}$ & 0 & 0,004 & 0,04 \\
\hline Сила тяжести бетонного блока, G, кг & 33,9 & 33,9 & 31,3 \\
\hline Архимедова сила, $\mathrm{P}_{\mathrm{a}}$, кг & 14,5 & 14,5 & 13,4 \\
\hline Сила пассивного отпора грунта, $F_{\text {or, }}$ кг & 0 & 0,599 & 6,51 \\
\hline $\begin{array}{l}\text { Сила гидростатического давления при } \\
\text { глубине } \mathrm{H}=1 \mathrm{M} \\
\mathrm{P}, \text { кг }\end{array}$ & 36,1 & 36,1 & 36,1 \\
\hline $\begin{array}{l}\text { Предельная скорость потока, способная } \\
\text { сместить УГЗБМ, U, м/с }\end{array}$ & 2,36 & 2,4 & 2,9 \\
\hline
\end{tabular}

Как видно из этой таблицы при расположении УГЗБМ на печчано-иловом грунте все модели обладают наибольшей устойчивостью, что обусловлено эффектом «присасывания», возникающим в этом случае на всех рассматриваемых моделях.

В табл.7 приведены расчетные параметры, соответствующие различным моделям УГЗБМ, уложенным на песчано-иловый грунт при различной глубине водотока. 
Таблица 7

Результаты расчета устойчивости УГЗБМ различных моделей, уложенных на песчано-иловый грунт при различной глубине водотока

\begin{tabular}{|l|c|c|c|c|c|c|}
\hline \multicolumn{2}{|l|}{ Глубина воды, Н, м } & 1 & 2 & 3 & 4 & 5 \\
\hline \multicolumn{2}{|l|}{ Сила гидростатического давления } & 36,1 & 72,2 & 108,3 & 144 & 180 \\
\hline \multirow{2}{*}{ Предельная скорость потока } & УГЗБМ-105 & 2,36 & 3,04 & 3,6 & 4,07 & 4,5 \\
\cline { 2 - 7 } \multirow{3}{*}{\begin{tabular}{l} 
U, м/с \\
\cline { 2 - 7 }
\end{tabular}} & УГЗБМ-105ш & 2.4 & 3,08 & 3,63 & 4,09 & 4,53 \\
\cline { 2 - 7 } & УГЗБМ-105п & 2,9 & 3,36 & 4,18 & 4,67 & 5,11 \\
\hline
\end{tabular}

Как видно из этой таблицы с ростом глубины водотока разница между устойчивостью различных моделей уменьшается. Так при глубине водотока $\mathrm{H}=5$ устойчивость УГЗБМ-105п только на 10\% выше устойчивости модели УГЗБМ-105.

\section{Общие выводы и рекомендации.}

Проведенные расчётно-теоретические сравнительные исследования гибких бетонных матов с усиленной шероховатостью и с «донной присоской» позволяют сделать следующие выводы:

1. Повышение устойчивости сдвигу гибких бетонных матов с усиленной шероховатостью при воздействии на них потока воды достигается за счёт увеличения силы трения шероховатой поверхности бетонного блока, о подстилающий грунт. Устойчивость таких матов определяется высотой выступов шероховатости и глубиной погружения их в грунт и существенно зависит от свойств защищаемого грунта.

2. Повышение устойчивости гибких бетонных матов $\mathrm{c}$ «донной присоской» достигается за счёт увеличения силы трения его о подстилающий грунт при действии силы гидростатического давления, прижимающей бетонный блок к защищаемой поверхности грунта. Наличие этой силы возможно только при плотном прилегании бетонного блока к водонепроницаемой или малопроницаемой грунтовой поверхности.

3. Использование гибких бетонных матов с «донной присоской» наиболее эффективно при защите глинистого грунта с проявлением эффекта 
«присасывания» бетонного блока к грунту, что достигается соответствующим выбором толщины кромки между выемкой и боковыми гранями бетонного блока. Толщина этой кромки должна выбираться из конструктивных соображений, учитывающих различные факторы.

4. Устойчивость гибких бетонных матов с «донной присоской» существенно повышается с увеличением глубины водотока, поэтому такие покрытия целесообразно применять при достаточно большой глубине водотока $(\mathrm{H}>1 \mathrm{M})$.

\section{Список литературы}

1. ТУ 5859-001-5956714-2009, Универсальный гибкий защитный бетонный мат (УГЗБМ).- Воронеж: ООО «Спецпром1», 2009.- 15с.

2. Гидравлические расчеты водосбросных гидротехнических сооружений: Справочное пособие.- М.: Энергоатомиздат, 1988.- 625c.

3. СП 32-103-97. Проектирование морских берегозащитных сооружений.- М.: Трансстрой, 1988-46с.

4. Гидротехнические сооружения, часть $1 /$ под ред. Гришина М.М.- М.: Высш. школа, 1979.- 615 c.

5. Юфин А.П. Гидромеханизация.- М.: Стройиздат, 1974.- $223 \mathrm{c}$.

6. Справочник по гидравлическим расчетам/под ред. П.Г.Киселева,- М.: Энергия, 1972.- 312c.

(C) Е.А. Завалина, 2021 